\title{
Chemical and Cytotoxic Investigation of Non-Polar Extract from Ceiba Pentandra (L.) Gaertn.: A Study Supported by Computer Based Screening
}

\author{
Mohamed E. Abouelela ${ }^{1}$, Mohamed A. A. Orabi ${ }^{1}$, Reda A. Abdelhamid ${ }^{1}$, Mohamed S. A. Abdelkader ${ }^{2 *}$, \\ Faten M. M. Darwish ${ }^{3}$ \\ ${ }^{1}$ Department of Pharmacognosy, Faculty of Pharmacy, Al-Azhar University, Assiut-Branch, Assiut, Egypt. \\ ${ }^{2}$ Department of Pharmacognosy, Faculty of Pharmacy, Sohag University, Sohag, Egypt. \\ ${ }^{3}$ Department of Pharmacognosy, Faculty of Pharmacy, Assiut University, Assiut, Egypt.
}

\begin{tabular}{|c|c|}
\hline ARTICLE INFO & ABSTRACT \\
\hline Artic & \multirow{8}{*}{$\begin{array}{l}\text { Nowadays, the discovery of new drugs from natural sources is increasing dramatically. Recently, the sight is directed } \\
\text { toward ornamental plants due to their sustainability. In this study, we are reporting on the gas chromatography profile } \\
\text { of fatty acids, other related lipids, and hydrocarbons of the non-polar methylene chloride (MC) fraction of the extract } \\
\text { of the ornamental tree Ceiba pentandra (L.) Gaertn. Chromatographic purification of the same fraction furnished eight } \\
\text { pure known constituents, } 3 \beta \text {-taraxerol (1), } 3 \beta \text {-taraxerol acetate }(\mathbf{2}) \text {, all-trans-squalene }(\mathbf{3}) \text {, oleic acid (4), 1-hexacosanol } \\
(\mathbf{5}), \beta \text {-amyrin }(\mathbf{6}), \beta \text {-sitosterol ( } 7 \text { ) and } \beta \text {-sitosterol-3-O- } \beta \text {-D-glucopyranoside }(\mathbf{8}) \text {, which are relatively abundant in the } \\
\text { fraction, six of them are firstly isolated from the plant (1-6). A computer-based bio-activity study indicated cancer } \\
\text { treatment and/or prevention of the isolated compounds }(\mathbf{1}-\mathbf{3} \text { and } \mathbf{6}) \text { with pa values higher than for the other predicted } \\
\text { effects. The experimental cytotoxicity assessment of the MC fraction demonstrated prominent cytotoxic effect against } \\
\text { the cancer cell lines HepG }\left(\mathrm{IC}_{50}=14.895 \mu \mathrm{g} / \mathrm{mL}\right) \text { and MCF-7 }\left(\mathrm{IC}_{50}=18.859 \mu \mathrm{g} / \mathrm{mL}\right) \text {. }\end{array}$} \\
\hline $2 / 05 / 2018$ & \\
\hline & \\
\hline Avail & \\
\hline Key words: & \\
\hline Ceiba pentandra, & \\
\hline & \\
\hline & \\
\hline
\end{tabular}

\section{INTRODUCTION}

Cancer is one of the major causes of mortality with higher levels in developing countries (Houghton et al., 2007). In Egypt, hepatocellular carcinoma (HCC) and breast cancer are the most serious cancer problems with elevated incidence rates [liver cancer (23.8\%), breast cancer (15.4\%)] (Ibrahim et al., 2014). Despite the successes in oncology chemotherapeutics, the impulse to develop novel, alternative or synergistic anti-cancer agents is becoming popular among the herbal medicine researchers to avoid the side effects imposed by recently used chemotherapeutics (Yin et al., 2013). Approximately $60 \%$ of drugs currently in clinical use for cancer treatment are obtained from natural sources as paclitaxel (Taxol) from yew (Taxus) species (Houghton et al., 2007).

\footnotetext{
${ }^{*}$ Corresponding Author

Mohamed S. A. Abdelkader, Faculty of Pharmacy, Sohag University, Sohag, Nasser City, 82524 Sohag, Egypt.

E-mail:msaladin2002@yahoo.com
}

Ceiba.pentandra (L.) Gaertn. (C. pentandra), also called Kapok and Silk-Cotton tree, is a fast-growing gigantic tree belongs to family Bombacaceae. It is widely distributed in the tropical, intertropical and subtropical regions of the world and planted as wayside and shade trees (Alvarado et al., 2002). The plant is used in folklore medicine as an emetic, diuretic, and antispasmodic (Lim, 2012). It is also recommended for the treatment of intestinal disorders (diarrhoea and dysentery), hormonal disease (diabetes) bone disease (arthritis), skin diseases, painful eye diseases, bronchitis, insect bites and chronic fever (Elumalai et al., 2012). Recent pharmacological studies revealed that solvent extracts of various parts of the plant have hypoglycaemic (Djomeni et al., 2006), hypolipidemic (Aloke et al., 2010), hepatoprotective (Bairwa et al., 2010), anti-inflammatory (Alagawadi and Shah, 2011), and anti-ulcerogenic effects.

In this study, a gas-chromatographic investigation of the non-polar fraction of the aerial parts extract of $C$. pentandra coupled with actual isolation by chromatography from the MC fraction led to the purification of eight major constituents (1-8). 
Moreover, employing prediction of activity spectra for substances (PASS) computer program revealed tumor treatment and/or prevention activities of these compounds. The experimental study on hepatocellular carcinoma (HepG2) and breast cancer (MCF-7) cell lines using SRB assay was also conducted.

\section{EXPERIMENTAL}

\section{General procedures}

Authentic $\beta$-sitosterol, $\beta$-amyrin and ceryl alcohol were obtained from the Pharmacognosy Department, Faculty of Pharmacy, Al-Azhar University, Assiut, Egypt. Silica gel (70-230 mesh, Merck, Germany) was used for column chromatography. Precoated silica gel $\left(\mathrm{G}_{60} \mathrm{~F}_{254}\right)$ plates (E. Merck, Darmstadt, Germany) were used for TLC analyses and spots were visualized by spraying with sulfuric acid $(10 \%$ in $\mathrm{MeOH})$ and heating at $110^{\circ} \mathrm{C}$ on a hot plate (Bolliger et al., 1970). The solvents petroleum ether, $n$-hexane, MC, EtOAc, n-butanol, acetone, ethanol, $\mathrm{MeOH}$ and DMSO and others were purchased from El-Nasr Pharmaceutical and Chemical Co., Egypt (ADWIC). ${ }^{1} \mathrm{H}$ and ${ }^{13} \mathrm{C}$ NMR spectra were recorded on Bruker Avance III $400 \mathrm{MHz}$ for ${ }^{1} \mathrm{H}$ and $100 \mathrm{MHz}$ for ${ }^{13} \mathrm{C}$ (Bruker AG, Switzerland) with BBFO smart probe and Bruker 400 AEON nitrogen-free magnet. Agilent 7890A network gas chromatograph with an Agilent 5975B inert XL EI/C/MSD mass selective detector with J\&W 122-5532 DB-5ms (30 m, $0.25 \mathrm{~mm}$, 0.25 um Film), (5\% Phenyl-methylpolysiloxane) capillary column (USA) was used for gas chromatography. The data were analyzed using Topspin 3.1 software.

\section{Plant material}

The fresh aerial parts, composed of leaves, petioles and young stems, of C. pentandra were collected at March 2017 from the field of ornamental plants, Faculty of Agriculture, Assiut University, Egypt. The plant was kindly identified by Dr. Essam Youssef, Associate Professor of Horticulture, Faculty of Agriculture, Assiut University, Egypt. A voucher specimen (No. Cpp1) was kept in Pharmacognosy Department, Faculty of Pharmacy, Al-Azhar University, Assuit-branch, Egypt. The plant materials were dried under shade, finely powdered and the powder was used for the extraction procedure.

\section{Cell lines}

MCF-7 and HepG-2 cancer cell lines were supplied by VACSERA, Egypt. The media (Dulbecco's modified Eagle's medium; DMEM) were sterilized by $0.22 \mu \mathrm{m}$ microbiological filters and kept at $4^{\circ} \mathrm{C}$ before use.

\section{A computer program for prediction of biological activity}

Prediction of Activity Spectra for Substances (PASS) program (ver. 4.20) was used for prediction of biological activity (Ramakrishnan, 2010).

\section{Extraction and isolation}

The air-dried powdered aerial parts $(2 \mathrm{~kg})$ of $C$. pentandra were extracted by maceration in $\mathrm{MeOH}-\mathrm{H}_{2} \mathrm{O}(8: 2$, $v / v)$ at room temperature $(5 \mathrm{~L} \times 3)$. The alcoholic extract was concentrated at $45^{\circ} \mathrm{C}$ under reduced pressure till constant weight $(250 \mathrm{~g})$. The dry methanolic extract was digested with distilled $\mathrm{H}_{2} \mathrm{O}(500 \mathrm{~mL})$. The suspension was transferred to a separating funnel and the phytoconstituents were successively partitioned between the aqueous layer and $\mathrm{MC}(500 \mathrm{~mL} \times 3)$, EtOAc $(500$ $\mathrm{mL} \times 3), n$-butanol $(500 \mathrm{~mL} \times 3)$ till exhaustion. Solvents of each fraction were distilled off then the fractions were dried under reduced pressure to give MC (52 g), EtOAc (28.06 g), n-butanol $(19.23 \mathrm{~g})$ and aqueous fractions $(149 \mathrm{~g})$, respectively.

\section{Investigation of lipids content}

Preparation of the unsaponifiable matter

A $0.2 \mathrm{~g}$ of the MC fraction was saponified by reaction with $40 \mathrm{~mL}$ of $20 \%$ ethanolic $\mathrm{KOH}$ overnight at room temperature. The alcohol was distilled off and the aqueous liquid was diluted with $\mathrm{H}_{2} \mathrm{O}$ then extracted with several portions of petroleum ether (40$60^{\circ} \mathrm{C}$ ) till exhaustion. The combined ethereal extract was washed with $\mathrm{H}_{2} \mathrm{O}$ and tested with litmus paper till the washings became free from any alkalinity then washed with $10 \% \mathrm{NaCl}$ solution. The ethereal extract was dehydrated over anhydrous sodium sulfate and then the ether was distilled off under reduced pressure to produce a viscous yellowish residue (unsaponifiable fraction). For detection of the hydrocarbons a $1 \mu \mathrm{L}$ of the unsaponifiable fraction was subjected to $\mathrm{GC}-\mathrm{MS}$ analysis at $40^{\circ} \mathrm{C}$ for $3 \mathrm{~min}$ then temperature increased by a rate of $10^{\circ} \mathrm{C} / \mathrm{min}$ till $150^{\circ} \mathrm{C}$ with holding time 3 min. then temperature increased by a rate of $10^{\circ} \mathrm{C} / \mathrm{min}$ to $220^{\circ} \mathrm{C}$ with holding time $6 \mathrm{~min}$. finally, temperature increased by a rate of $15^{\circ} \mathrm{C} / \mathrm{min}$ till $260^{\circ} \mathrm{C}$ with holding time $13 \mathrm{~min}$. GC-MS analysis for detection of steroids and terpenes was performed at $100^{\circ} \mathrm{C}$ for $1 \mathrm{~min}$ then temperature increased by a rate of $10^{\circ} \mathrm{C} / \mathrm{min}$ to $260^{\circ} \mathrm{C}$ with holding time for $29 \mathrm{~min}$ (El-Saied et al., 1981).

\section{Fatty acids analysis}

The alkaline aqueous solution (soap) left after extraction of the unsaponifiable matter was acidified with a dilute sulphuric acid, and the liberated fatty acids were extracted with petroleum ether $\left(40-60^{\circ} \mathrm{C}\right)(50 \mathrm{~mL} \times 3)$. The combined ethereal extracts were washed several times with distilled $\mathrm{H}_{2} \mathrm{O}$ and tested with litmus paper until the washings were free from acidity then washed by $10 \% \mathrm{NaCl}$ solution. The ether extract was dried over anhydrous sodium sulfate. The solvent was distilled off under reduced pressure to give a viscous residue of the free fatty acids.

The free fatty acids were dissolved in little absolute $\mathrm{MeOH}$ in a glass tube and esterified by cooling in ice and adding an ethereal solution of diazomethane in small portions until gas evolution ceases and the solution acquires a pale yellow color. The solvent was evaporated under reduced pressure, the residue was digested with little $\mathrm{H}_{2} \mathrm{O}$, and then extracted with ether several times (each of $10 \mathrm{~mL}$ ). The combined ethereal extracts were dehydrated over anhydrous sodium sulfate, and the solvent was then concentrated to yield an oily residue (methyl esters). A $1 \mu \mathrm{L}$ of the obtained methyl esters was subjected to GC-MS analysis at $80^{\circ} \mathrm{C}$ for $2 \mathrm{~min}$ then temperature increased by a rate of $3^{\circ} \mathrm{C} / \mathrm{min}$ till 230 with holding time $5 \mathrm{~min}$ for each $40 \mathrm{~min}$ (El-Sayeda et al., 2013).

\section{Chromatographic isolation of major constituents of $\mathrm{MC}$ fraction}

A part of the MC fraction (30 g) was chromatographed over silica gel (70-230 mesh, $600 \mathrm{~g}$ ), eluted with $n$-hexane and $n$-hexane-EtOAc gradients with a collection of $100 \mathrm{~mL}$ aliquot. 
Similar fractions were grouped together, concentrated under reduced pressure to give six fractions (M-I-M-VI). The fraction M-II (2.576 g), eluted with $n$-hexane-EtOAc $(97: 3, v / v)$, was crystallized from $\mathrm{MC}$ to give $3 \beta$-taraxerol acetate $(2,21 \mathrm{mg})$. The fraction M-III (200 mg), eluted with $n$-hexane-EtOAc $(95: 5, v / v)$, was re-chromatographed on silica gel column chromatography $(10 \mathrm{~g})$ and eluted with $n$-hexane-EtOAc $(97: 3, v / v)$ isocratically and afforded $\beta$-amyrin $(6,9 \mathrm{mg})$. The fraction M-IV $(650 \mathrm{mg})$, eluted with $n$-hexane-EtOAc $(9: 1, v / v)$, was re-chromatographed on silica gel column chromatography $(25 \mathrm{~g})$ and eluted with $n$-hexane-EtOAc $(9: 1, v / v)$ isocratically and afforded 3 subfractions (M-IV-1-M-IV-3). Both M-IV-2 (200 mg) and M-IV-3 $(120 \mathrm{mg})$ sub-fractions were recrystallized from MC and furnished $3 \beta$-taraxerol (1,90 $\mathrm{mg})$ and $\beta$-sitosterol $(7,70 \mathrm{mg}$ ), respectively. The sub-fraction M-IV-1 (162 mg) was re-chromatographed on silica gel (10 g) and eluted with $n$-hexane-MC-EtOAc (60:20:2.5, $v / v / v)$ isocratically and yielded another two sub-fractions M-IV1-A (98 mg) and M-IV-1-B (18 mg). The sub-fraction M-IV-1-B was dissolved in $\mathrm{MC}$ and left overnight where hexacosanol $(\mathbf{5}, 12$ mg) gave an amorphous precipitate. The M-IV-1-A sub-fraction was re-chromatographed on silica gel $(162 \mathrm{mg})$ and eluted with $n$-hexane-EtOAc $(95: 5, v / v)$ isocratically to give all-trans-squalene $(3,9 \mathrm{mg})$ and oleic acid $(4,15 \mathrm{mg})$ in subsequent elutes. A part of fraction M-V (200 mg) eluted with $n$-hexane-EtOAc (80:20, $v / v)$ was re-chromatographed on silica gel $(10 \mathrm{~g})$ and eluted with $\mathrm{MC}-\mathrm{MeOH}(90: 10, v / v)$ isocratically and afforded $\beta$-sitosterol-3$O$ - $\beta$-D-glucopyranoside $(\mathbf{8}, 29 \mathrm{mg})$.

Cytotoxic activity of MC fraction of $C$. pentandra (L.) Garten. var. pentandra

The cytotoxic activity of the MC fraction was conducted against two cancer cell lines HepG-2 and MCF-7 using sulforhodamine B cytotoxicity assay method (Priya et al., 2015; Ul-Haq et al., 2012). All experiments were carried out in triplicate (El-Hawary et al., 2015).

Data are expressed as the percentage of relative viability, which was calculated using the following equation:

$$
\text { Relative viability }=\frac{\text { treated cells absorbance }}{\text { control cells absorbance }} \times 100
$$

Cell survival was measured as the percentage of absorbance compared with the control. The positive cytotoxic activity is indicated by less than $100 \%$ relative viability. The relation between surviving fraction and extract concentration is plotted to get the survival curve of the liver, and breast cell lines. Also, the $\mathrm{IC}_{50}$ (dose of the extract which reduces survival to $50 \%$ ) for active extracts was calculated using Sigma plot 12 computer software.

\section{RESULTS AND DISCUSSION}

\section{Investigation of unsaponifiable matter composition}

Fatty acids, steroids, and other unsaponifiable substances are widely distributed in non-polar fractions of plant extracts. The characterization of their profiles and relative proportions can serve as a fingerprint for identification of plants and as a parameter in identifying and detecting adulterant (Bezerra and Antoniosi Filho,
2014). Unsaturated fatty acids play an essential role in stabilization and function of biological membranes of living organisms (Zhang et al., 2004). Moreover, they have hypolipidemic properties against triglycerides and may also reduce the developing of colon, breast, and prostate cancers (Lunn and Theobald, 2006). In addition, several chemotherapeutic agents-unsaturated fatty acids conjugates prodrugs and prodrug-based nanoparticulate drug delivery systems are talented prospects for developing potential chemotherapeutic applications in cancer treatment (Sun et al., 2017). Plant-derived sterols are also important natural products since they have known for their potential treatment and prevention of cardiovascular diseases (Maeorg et al., 2007).

The unsaponifiable matters were identified by matching their retention times and fragmentation patterns with those of reference compounds analyzed under the same conditions by gas-liquid chromatography (GLC). The major known identified hydrocarbons are listed in table 1; they include 3-ethyltetracosane (4.82\%), n-nonacosane (4.79\%), $n$-docosane $(4.71 \%)$ and $n$-pentacosane $(4.31 \%)$. Meanwhile, the major known sterols and terpenes are phytol $(14.99 \%)$, taraxerol $(14.01 \%), \beta$-sitosterol $(11.87 \%)$ and squalene $(9.96 \%)$ as listed in table 2.

Table 1: GLC analysis results of unsaponifiable fraction (Hydrocarbons) of $C$. pentandra.

\begin{tabular}{|c|c|c|c|}
\hline NO. & Name & $t_{\mathrm{R}}(\min )$ & Relative \% \\
\hline 1 & 1-Hexadecene & 21.544 & $1.01 \%$ \\
\hline 2 & Cycloeicosane & 23.948 & $1.39 \%$ \\
\hline 3 & 5-Eicosene & 26.551 & $1.24 \%$ \\
\hline 4 & $n$-Hexadecane & 26.631 & $0.94 \%$ \\
\hline 5 & 2,6,11-Trimethyl-dodecane & 28.525 & $1.72 \%$ \\
\hline 6 & Cyclotetracosane & 30.745 & $0.67 \%$ \\
\hline 7 & $n$-Tetracosane & 30.843 & $3.15 \%$ \\
\hline 8 & $n$-Pentacosane & 32.342 & $4.31 \%$ \\
\hline 9 & $n$-Docosane & 33.498 & $4.71 \%$ \\
\hline 10 & 5,9-Dimethyl-4,10-octadecadiene & 34.282 & $0.89 \%$ \\
\hline 11 & 3-Ethyltetracosane & 34.802 & $4.82 \%$ \\
\hline 12 & $n$-Nonadecane & 36.382 & $3.87 \%$ \\
\hline 13 & $n$-Nonacosane & 38.316 & $4.79 \%$ \\
\hline 14 & (5E)-2,3,5,8-Tetramethyl-1,5,9-decatriene & 38.67 & $1.19 \%$ \\
\hline 15 & 2-Methyl-7-nonadecene & 39.792 & $3.25 \%$ \\
\hline 16 & 1,19-Eicosadiene & 40.524 & $0.92 \%$ \\
\hline 17 & 17-Pentatriacontene & 43.826 & $2.78 \%$ \\
\hline 18 & 9-Tricosene & 44.038 & $0.98 \%$ \\
\hline
\end{tabular}

\section{Investigation of the fatty acids composition}

The fatty acids methyl esters were identified by matching their retention times and fragmentation patterns with those of reference compounds analyzed under the same conditions. The identified fatty acids with their relative abundance in the MC fraction of aerial parts of $C$. pentandra are linoleic acid (34.38\%), $\alpha$-linolenic acid (17.47\%), palmitic acid (17.30\%), stearic acid (14.22\%), myristic acid (12.26\%) and oleic acid (4.37\%).

\section{Identification of isolated compounds}

The MC fraction of $C$. pentandra was subjected to several chromatographic techniques, where eight (1-8) 
compounds were purified, six of them (1-6), are firstly isolated from the plant. The compounds were identified by comparison of their chromatographic, physical, chemical and spectroscopic data with literature data as $3 \beta$-taraxerol (1), $3 \beta$-taraxerol acetate (2), all-trans-squalene (3), oleic acid (4), 1-hexacosanol (5), $\beta$-amyrin, (6), $\beta$-sitosterol (7) and $\beta$-sitosterol-3- $O$ - $\beta$-D-glucopyranoside (8) (Fig. 1). The physico-chemical and spectroscopic data of the isolated compounds are as follow:

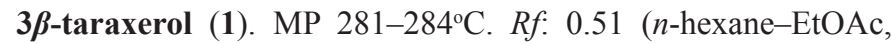
80:20). ${ }^{1} \mathrm{H}$ NMR (400 MHz, $\left.\mathrm{CDCl}_{3}\right): 0.80(3 \mathrm{H}, \mathrm{s}, \mathrm{H}-24), 0.82(3 \mathrm{H}$, s, H-28), 0.88 (1H, m, H-5), 0.91 (3H, s, H-27), 0.91 (3H, s, H-30), 0.92 (3H, s, H-25), 0.95 (3H, s, H-29), 0.97 (3H, s, H-23), 0.99 (1H, m, H-1), 0.99 (1H, m, H-18), 1.00 (1H, m, H-22), 1.02 (1H, m, H-19), 1.10 (3H, s, H-26), 1.25 (2H, m, H-21), $1.33(1 \mathrm{H}, \mathrm{m}$, H-19), 1.36 (1H, m, H-7), 1.38 (1H, m, H-21), 1.38 (1H, m, H-22), 1.43 (1H, m, H-9), 1.45 (1H, m, H-6), 1.49 (1H, m, H-11), 1.53 (1H, m, H-12), 1.59 (1H, m, H-16), 1.62 (1H, m, H-6), $1.62(2 \mathrm{H}$, m, H-2), $1.63(1 \mathrm{H}, \mathrm{m}, \mathrm{H}-11), 1.63(1 \mathrm{H}, \mathrm{m}, \mathrm{H}-1), 1.64(1 \mathrm{H}, \mathrm{m}$, $\mathrm{H}-12), 1.92(1 \mathrm{H}, \mathrm{dd}, \mathrm{J}=14.8,3.2 \mathrm{~Hz}, \mathrm{H}-16), 2.03(1 \mathrm{H}, \mathrm{dt}, \mathrm{J}=12.5$, $3.0 \mathrm{~Hz}, \mathrm{H}-7), 3.19$ (1H, dd, J = 11.2, $4.8 \mathrm{~Hz}, \mathrm{H}-3), 5.53$ (1H, dd, J $=8,3.2 \mathrm{~Hz}, \mathrm{H}-15)$.

Table 2: GLC analysis results of unsaponifiable fraction (sterols and terpenes) of $C$. pentandra.

\begin{tabular}{cccc}
\hline No. & Name & $\boldsymbol{t}_{\mathrm{R}}(\mathbf{m i n})$ & Relative $\%$ \\
\hline 1 & $3 \beta$-Hydroxy-androst-5-ene-17-one & 10.632 & $0.15 \%$ \\
2 & $6,10,14$-Trimethyl-2-pentadecanone & 11.654 & $0.76 \%$ \\
3 & $\gamma$ cis-Sesquicyclo geraniol & 12.385 & $1.04 \%$ \\
4 & Phytol & 14.286 & $14.99 \%$ \\
5 & Stearyl alcohol & 15.027 & $0.90 \%$ \\
6 & Phytane & 15.943 & $1.69 \%$ \\
7 & trien-2-one & 16.589 & $0.96 \%$ \\
8 & Squalene & 21.456 & $9.96 \%$ \\
9 & Farnesol & 23.505 & $1.04 \%$ \\
10 & $\beta$-Sitosterol & 36.166 & $11.87 \%$ \\
11 & Taraxerol & 36.701 & $14.01 \%$ \\
\hline
\end{tabular}

${ }^{13} \mathrm{C}$ NMR (100 MHz, $\left.\mathrm{CDCl}_{3}\right): 15.6(\mathrm{C}-24), 15.6(\mathrm{C}-25)$, 17.7 (C-11), 18.9 (C-6), 21.5 (C-27), 26.1 (C-26), 27.3 (C-2), 28.2 (C-23), 28.9 (C-20), 29.9 (C-28), 30.1 (C-30), 33.2 (C-12), 33.5 (C-29), 33.8 (C-21), 35.3 (C-17), 35.9 (C-22), 36.8 (C-16), 37.7 (C-19), 37.9 (C-13), 37.9 (C-10), 38.1 (C-1), 38.9 (C-4), 39.1 (C-8), 41.5 (C-7), 48.9 (C-9), 49.4 (C-18), 55.7 (C-5), 79.2 (C-3), 117.0 (C-15), 158.2 (C-14).

EIMS: [M] $]^{+}$ion at $m / z=426.30$.

3 $\beta$-taraxerol acetate (2). MP $304-305^{\circ} \mathrm{C} . R f: 0.3$ (n-hexaneEtOAc, 90:10). ${ }^{1} \mathrm{H}$ NMR (400 MHz, $\left.\mathrm{CDCl}_{3}\right)$ : 0.81 (3H, s, H-30), 0.85 (3H, s, H-29), 0.87 (3H, s, H-28), $\delta_{\mathrm{H}} 0.90$ (3H, s, H-27), 0.91 (3H, s, H-25), 0.94 (1H, m, H-18), 0.94 (3H, s, H-23), 0.94 (3H, s, H-24), 0.97 (1H, m, H-5), 0.98 (1H, m, H-1), 1.09 (3H, s, H-26), 1.35 (1H, m, H-1), 1.36 (1H, m, H-7), 1.36 (2H, m, H-21), 1.45 (1H, m, H-6), 1.45 (2H, m, H-22), 1.53 (1H, m, H-9), 1.53 (2H, m, H-11), 1.59 (2H, m, H-2), 1.61 (1H, m, H-6), 1.61 (2H, m, H-12), 1.61 (2H, m, H-19), 1.92 (2H, m, H-16), 2.01 (1H, m, H-7), 2.04 $\left(3 \mathrm{H}, \mathrm{s}, \mathrm{C}_{3} \mathrm{COO}\right), 4.46(1 \mathrm{H}, \mathrm{dd}, J=9.6,5.2 \mathrm{~Hz}, \mathrm{H}-3), 5.53(1 \mathrm{H}$, dd, $J=7.6,2.4 \mathrm{~Hz}, \mathrm{H}-15)$.
${ }^{13} \mathrm{C}$ NMR (100 MHz, $\left.\mathrm{CDCl}_{3}\right): 15.7$ (C-25), 16.7 (C-24), 17.7 (C-11), 18.8 (C-6), $21.4\left(\underline{\mathrm{CH}}_{3} \mathrm{COO}\right), 21.5$ (C-30), 23.6 (C-2), 26.1 (C-26), 28.1 (C-23), 28.9 (C-20), 30.0 (C-28), 30.1 (C-27), 33.2 (C-7), 33.5 (C-29), 33.8 (C-16), 35.3 (C-21), 35.9 (C-17), 36.8 (C-12), 37.5 (C-22), 37.7 (C-10), 37.8 (C-1), 37.8 (C-13), 38.0 (C-4), 39.1 (C-8), 41.4 (C-19), 48.9 (C-18), 49.3 (C-9), 55.8 (C-5), 81.2 (C-3), 117.1 (C-15), 158.1 (C-14), 171.1 (ㅁO).

All-trans-squalene (3). $R f: 0.9$ ( $n$-hexane-MC, 70:30).

${ }^{1} \mathrm{H}$ NMR (400 MHz, $\left.\mathrm{CDCl}_{3}\right): 1.60$ (18H, s, H-24-29), 1.68 (6H, s, H-1, 30), 2.10-1.95 (20H, m, H-4, 5, 8, 9, 12, 13, 16, 17, 20, 21), 5.15-5.08 (6H, m, H-2, 6, 10, 14, 18, 22).

EIMS: $[\mathrm{M}]^{+}$ion at $m / z=410$.

Oleic acid (4) Rf: 0.35 (n-hexane-MC, 40:60). ${ }^{1} \mathrm{H}$ NMR (400 $\mathrm{MHz}, \mathrm{CDCl}_{3}$ ): 0.88 (3H, t, $\left.J=7.2 \mathrm{~Hz}, \mathrm{H}-18\right), 1.29$ (8H, m, H-4-H7), 1.29 (12H, m, H-12-H-17), 1.63 (2H, m, H-3), 2.00 (4H, m, H-8, H-11), 2.34 (2H, t, J=7.6 Hz, H-2), 5.34 (1H, m, H-9, H-10), $11.22(1 \mathrm{H}$, br. s., $\mathrm{COOH})$.

${ }^{13} \mathrm{C}$ NMR (100 MHz, $\left.\mathrm{CDCl}_{3}\right): 14.2$ (C-18), 22.8 (C-17), 24.8 (C-16), 27.3 (C-11), 27.4 (C-8), 29.2 (C-4), 29.2 (C-6), 29.3 (C-5), 29.5 (C-13), 29.5 (C-15), 29.7 (C-14), 29.8 (C-7), 29.9 (C-12), 32.1 (C-3), 34.3 (C-2), 129.8 (C-9), 130.1 (C-10), 180.7 (C-1). EIMS: $[\mathrm{M}]^{+}$ion at $m / z=282$.

1-Hexacosanol (5). EIMS: $[\mathrm{M}]^{+}$ion at $\mathrm{m} / \mathrm{z}=364 .{ }^{1} \mathrm{H}$ NMR $(400$ $\left.\mathrm{MHz}, \mathrm{CDCl}_{3}\right)$ : 0.91 (3H, t, H-26), 1.59 (2H, m, H-3), $1.80(46 \mathrm{H}$, br. s., H-4-H-25), 3.67 (2H, t, H-1).

B-Amyrin (6). MP 200-203ㄷ. Rf: 0.43 (n-hexane-MC, 40:60). EIMS: $m / z=426$.

$\boldsymbol{\beta}$-Sitosterol (7). MP $134-136^{\circ} \mathrm{C}$. Rf: 0.43 ( $n$-hexane-EtOAc, $85: 15)$.

${ }^{1} \mathrm{H}$ NMR (400 MHz, $\left.\mathrm{CDCl}_{3}\right): 0.68(3 \mathrm{H}, \mathrm{s}, \mathrm{H}-18), 0.81$ $(3 \mathrm{H}, \mathrm{d}, J=7.2 \mathrm{~Hz}, \mathrm{H}-26), 0.83(3 \mathrm{H}, \mathrm{d}, J=7.2 \mathrm{~Hz}, \mathrm{H}-27), 0.84(3 \mathrm{H}$, t, $J=7.0 \mathrm{~Hz}, \mathrm{H}-29), 0.92(3 \mathrm{H}, \mathrm{d}, J=6.4 \mathrm{~Hz}, \mathrm{H}-21), 1.00(3 \mathrm{H}, \mathrm{s}$, H-19), 3.51 (1H, m, H-3), 5.35 (1H, d, J=5.2 Hz, H-6).

${ }^{13} \mathrm{C}$ NMR (100 MHz, $\left.\mathrm{CDCl}_{3}\right): 12.0$ (C-18), 12.1 (C-29), 18.9 (C-27), 19.2 (C-21), 19.6 (C-19), 20.0 (C-26), 21.2 (C-11), 23.2 (C-28), 24.5 (C-15), 26.2 (C-23), 28.4 (C-16), 29.3 (C-25), 31.8 (C-7), 32.1 (C-2), 32.1 (C-8), 34.1 (C-22), 36.3 (C-20), 36.7 (C-10), 37.4 (C-1), 39.9 (C-12), 42.4 (C-4), 42.5 (C-13), 46.0 (C-24), 50.3 (C-9), 56.2 (C-17), 56.9 (C-14), 71.9 (C-3), 121.9 (C-6), 140.9 (C-5).

$\boldsymbol{\beta}$-Sitosterol-3- $\boldsymbol{O}$ - $\boldsymbol{\beta}$-D-glucopyranoside $\quad(8)$. $R f: 0.54 \quad(\mathrm{MC}-$ $\left.\mathrm{MeOH}-\mathrm{H}_{2} \mathrm{O}, 80: 20: 0.1\right)$.

${ }^{1} \mathrm{H}$ NMR (400 MHz, DMSO- $d_{6}$ ): 0.66 (3H, s, H-18), 0.79 $(3 \mathrm{H}, \mathrm{d}, J=7.2 \mathrm{~Hz}, \mathrm{H}-27), 0.81$ (3H, d, $J=6.8 \mathrm{~Hz}, \mathrm{H}-26), 0.83$ $(3 \mathrm{H}, \mathrm{t}, J=7 \mathrm{~Hz}, \mathrm{H}-29), 0.88(1 \mathrm{H}, \mathrm{m}, \mathrm{H}-9), 0.91(3 \mathrm{H}, \mathrm{d}, J=6.4 \mathrm{~Hz}$, H-21), 0.91 (1H, m, H-24), 0.96 (3H, s, H-19), 0.99 (1H, m, H-17), 1.01 (2H, m, H-1, H-22), 1.05 (1H, m, H-15), 1.09 (1H, m, H-14), 1.14 (1H, m, H-12), 1.17 (2H, m, H-23), 1.32 (1H, m, H-22), 1.34 (lH, m, H-20), 1.39 (2H, m, H-8, H-11), 1.49 (3H, m, H-2, H-28), 1.50 (3H, m H-11, H-15, H-16), 1.63 (1H, m, H-25), 1.80 (3H, m, H-1, H-16, H-28), 1.93 (2H, m, H-7), 1.95 (1H, m, H-12), 2.12 (1H, m, H-4), 2.36 (1H, m, H-4), 3.48 (1H, m, H-3), 5.33 (1H, d, $J=4.8 \mathrm{~Hz}, \mathrm{H}-6)$; glucose; 2.89 (1H, m, H-2'), 3.03 (1H, m, H-4'), $3.06\left(1 \mathrm{H}, \mathrm{m}, \mathrm{H}-5^{\prime}\right), 3.12\left(1 \mathrm{H}, \mathrm{m}, \mathrm{H}-3^{\prime}\right), 3.40(1 \mathrm{H}, \mathrm{dd}, J=11.6,5.6$ Hz, H-6'), 3.64 (1H, dd, $\left.J=11.6,1.6 \mathrm{~Hz}, \mathrm{H}-6^{\prime}\right), 4.22(1 \mathrm{H}, \mathrm{d}, J=$ $7.6 \mathrm{~Hz}, \mathrm{H}-1^{\prime}$ ). 


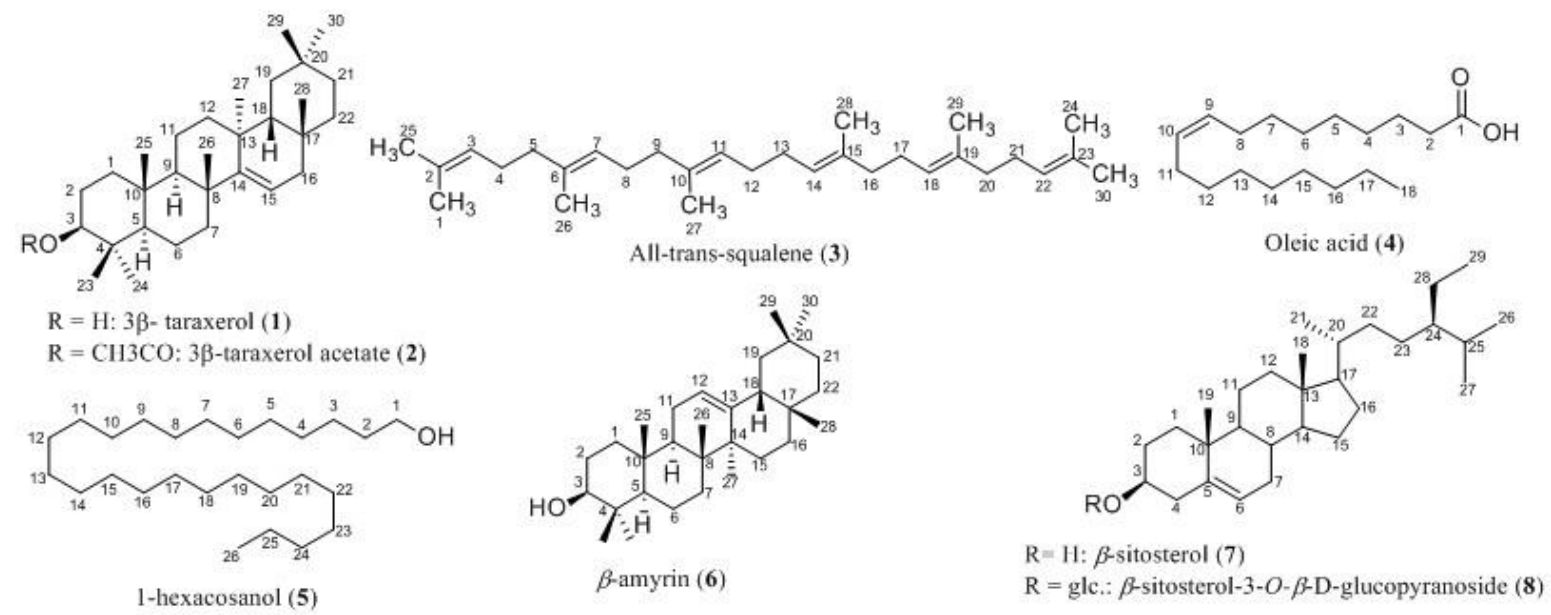

Fig. 1: Structures of isolated compounds.

${ }^{13} \mathrm{C}$ NMR (100 MHz, DMSO-d $): 11.7$ (C-26), 11.8 (C-18), 18.6 (C-21), 18.9 (C-27), 19.1 (C-19), 19.7 (C-29), 20.6 (C-11), 22.6 (C-15), 23.8 (C-23), 25.5 (C-16), 27.8 (C-25), 28.7 (C-2), 29.3 (C-28), 31.4 (C-7), 31.4 (C-8), 33.4 (C-22), 35.5 (C-20), 36.2 (C-10), 36.8 (C-1), 38.3 (C-4), 41.8 (C-12), 41.8 (C-13), 45.2 (C-24), 49.6 (C-9), 55.4 (C-14), 56.2 (C-17), 76.9 (C-3), 121.2 (C-6), 140.4 (C-5); glucose; $61.1\left(\mathrm{C}-6^{\prime}\right), 70.1$ (C-4'), 73.4 (C-2'), 76.7 (C-5'), 76.9 (C-3'), 100.8 (C-1').

$\boldsymbol{3} \boldsymbol{\beta}$-Taraxerol (1, Fig. 1) was obtained from MC fraction as cubic crystals $\left(\mathrm{CH}_{2} \mathrm{Cl}_{2}\right)(21 \mathrm{mg})$. The ${ }^{1} \mathrm{H}$ NMR data of 1 revealed the presence of a double doublet at $\delta_{\mathrm{H}} 5.53(1 \mathrm{H}, \mathrm{dd}, J=8,3.2 \mathrm{~Hz})$ attributable to an olefenic proton. The signal at $\delta_{\mathrm{H}} 3.18(1 \mathrm{H}$, dd, $J=11.2,4.8 \mathrm{~Hz}$ ) is attributable to an oxymethine proton. Six $3 \mathrm{H}$ singlets at $\delta_{\mathrm{H}} 1.08,0.98,0.94,0.92,0.82$ and 0.80 are assignable to six methyl protons. Another singlet integrating for six protons at $\delta_{\mathrm{H}} 0.90$ is due to protons of two equivalent methyl moieties.

The ${ }^{13} \mathrm{C}$ NMR spectrum showed carbon peaks at $\delta_{\mathrm{C}}$ $28.15,15.58,15.61,26.06,21.47,29.98,33.5,30.08$ assignable to eight methyl carbons. The carbon peaks at $\delta_{\mathrm{C}} 158.22$ and 117.02, C-14 and C-15, respectively, agree with the presence of double bond involving quaternary carbon atom. The chemical shift at $\delta_{\mathrm{C}} 79.22$ due to an $\mathrm{sp}^{3}$ hybridized carbon attached to an $\mathrm{OH}$ group is assignable for the $\mathrm{C}-3$. The remaining chemical shifts (experimental section) were consistent with the other carbon atoms of $3 \beta$-taraxerol in the published data (Ha, 2014).

The EI mass spectrum (supplementary data) showed a molecular ion peak at $\mathrm{m} / z=426.30$ with fragmentation pattern consistent with the reported fragmentation pattern of pentacyclic triterpes (Shiojima et al., 1992). Compound 1 was identified as $3 \beta$-taraxerol by comparison of the chromatographic and spectroscopic $\left({ }^{1} \mathrm{H}\right.$ and ${ }^{13} \mathrm{C}$ NMR and EIMS) with the reported data (Ha, 2014; Koay et al., 2013). This compound is firstly reported from the family Bombacaceae.

$3 \boldsymbol{\beta}$-Taraxerol acetate (2, Fig. 1) was obtained from MC fraction as colorless needle crystals, $(21 \mathrm{mg})$. The ${ }^{1} \mathrm{H}$ NMR spectrum of $\mathbf{2}$ (supplementary data) revealed an olefinic proton signal at $\delta_{\mathrm{H}} 5.53$ $(1 \mathrm{H}, \mathrm{dd}, J=7.6,2.4 \mathrm{~Hz})$, an oxymethine proton signal $\left(\delta_{\mathrm{H}} 4.48\right.$, dd, $J=9.6,5.2 \mathrm{~Hz})$, and eight $3 \mathrm{H}$-singlets $\left(\delta_{\mathrm{H}} 1.08,0.94,0.94,0.90\right.$, $0.89,0.87,0.85,0.81)$ closely related to those of $3 \beta$-taraxerol (1).
A characteristics signal at $\delta_{\mathrm{H}} 2.04(3 \mathrm{H}, \mathrm{s})$ indicates the presence of acetyl moiety, which is placed at $\mathrm{C}-3$ because of the resonance of H-3 at more downfield shift $\left(\delta_{\mathrm{H}} 4.46\right)$ lower than that $\left(\delta_{\mathrm{H}} 3.19\right)$ of the free hydroxylated analog $(3 \beta$-taraxerol, 1$)$. The ${ }^{13} \mathrm{C} N M R$ spectrum (supplementary data) showed thirty-two carbon peaks. Among them, the signal at $\delta_{\mathrm{C}} 171.08$ was attributed to the carbonyl of the acetate function (Mahato and Kundu, 1994). Placement of the acetate group at C-3 was also supported by the downfield shift of the C-3 carbon $\left(\delta_{\mathrm{C}} 81.17\right)$ instead of $\left(\delta_{\mathrm{C}} 79.1\right)$ of taraxerol (Muithya, 2010). The ${ }^{13} \mathrm{C}$ NMR spectrum also showed signals at $\delta_{\mathrm{C}} 158.12$ and $\delta_{\mathrm{C}} 117.08$ due to double bond functionality, C-14, and $\mathrm{C}-15$, respectively. The spectrum also showed eight carbon peaks at $\delta_{\mathrm{C}} 15.65,16.74,21.47,26.07,28.13,29.98,30.07$ and 33.3 , diagnostic for the eight methyl carbons of the pentacyclic triterpenoidal skeleton.

The ${ }^{1} \mathrm{H}$ and ${ }^{13} \mathrm{C}$ NMR data of 2 are identical to the published data of $3 \beta$-taraxerol acetate (Sasaki et al., 1965). It is reported from the genus Ceiba for the first time.

All-trans-squalene (3, Fig. 1) was obtained as pale yellow oily residue, ( $9 \mathrm{mg}$ ). The EIMS spectrum (supplementary data) showed a molecular ion peak at $m / z 410\left[\mathrm{M}^{+}\right]$and diagnostic ion peaks at $m / z=367\left[\mathrm{M}^{+}-\mathrm{C}_{3} \mathrm{H}_{7}\right], 341\left[\mathrm{M}^{+}-\mathrm{C}_{5} \mathrm{H}_{9}\right]$ and a base peak at $m / z=69$. Other significant fragment ions observed were at $\mathrm{m} / \mathrm{z} 81,83,95$, $107,121,136$. In general, this mass ionization pattern indicates a 410 molecular mass compound of $\mathrm{C}_{30} \mathrm{H}_{50}$ formula which is the same as those for all-trans-squalene (3) (Dagan and Amirav, 1995). The ${ }^{1} \mathrm{H}$ NMR spectrum of $\mathbf{3}$ (supplementary data) showed the presence of signals of 6 olefinic protons at $\delta_{\mathrm{H}} 5.15-5.08(6 \mathrm{H}$, $\mathrm{m})$, cluster of 10 methylene proton signals at $\delta_{\mathrm{H}} 2.09-1.97(20 \mathrm{H}$, $\mathrm{m})$, two equivalent methyl signals $1.68(6 \mathrm{H}, \mathrm{s})$, and 6 equivalent methyl signals $1.60(18 \mathrm{H}, \mathrm{s})$ which are the same as those reported in literature for all-trans-squalene (Pogliani et al., 1994). It is reported from the genus Ceiba for the first time.

Oleic acid (4, Fig. 1) was obtained as a colorless liquid, (15 mg). The EIMS spectrum (supplementary data) of $\mathbf{4}$ showed weak [M] $]^{+}$ ion at $m / z=282$ and an ion representing the loss of the elements of $\mathrm{H}_{2} \mathrm{O}$ from a carboxyl group $\left([\mathrm{M}-18]^{+}, m / z=264\right)$. The ${ }^{1} \mathrm{H}$ NMR data (experimental section) indicated the presence of a methyl moiety $\left(\delta_{\mathrm{H}} 0.88,3 \mathrm{H}, \mathrm{t}, J=7.2 \mathrm{~Hz}\right)$, cluster of $\mathrm{CH}_{2}$ groups $\left(\delta_{\mathrm{H}}\right.$ 
$1.26-1.32,20 \mathrm{H}$, br. s.), a $\mathrm{CH}_{2}$ group neighbor to carboxylic moiety $\left(\delta_{\mathrm{H}} 2.34,2 \mathrm{H}, \mathrm{t}, J=7.6 \mathrm{~Hz}\right)$, two olefinic protons $\delta_{\mathrm{H}} 5.34(2 \mathrm{H}, \mathrm{m})$ and a carboxylic group $\left(\delta_{\mathrm{H}} 11.22,1 \mathrm{H}\right.$, br. s.). These were further confirmed from the ${ }^{13} \mathrm{C}$ NMR spectrum (supplementary data) by the presence of corresponding carbon peaks at $\delta_{\mathrm{C}} 14.23, \delta_{\mathrm{C}} 22.83-$ $34.27, \delta_{C} 129.83,130.13$ and $\delta_{C} 180.72$, respectively. From the above-mentioned data, which agree with the previously published data (Sahu et al., 2013), the compound was identified as oleic acid. It was previously reported from $C$. pentandra species (Anwar et al., 2014).

1-Hexacosanol (= ceryl alcohol, 5, Fig. 1), was obtained as white flakes $(\mathrm{MeOH}),(12 \mathrm{mg})$. The EIMS spectrum (supplementary data) of 5 exhibited fragment ion peaks $(\mathrm{m} / \mathrm{z}=364$ and 336) consistent with the loss of $\mathrm{H}_{2} \mathrm{O}$ and $\left[\mathrm{CH}_{2}=\mathrm{CH}_{2}\right]^{+}$from a long chain alcohol (Dass, 2007). The examination of the rest of the fragmentation pattern showed an even cascade of [M-14] $\left(\mathrm{CH}_{2}{ }^{-}\right)$ characteristic for saturated linear hydrocarbons. The fragments observed are consistent with the expected fragmentation of a long chain aliphatic alcohol with the molecular weight of 382 and by comparison with the reported data it found to be identical for ceryl alcohol (Joshi and Poudel, 2013). The ${ }^{1} \mathrm{H}$ NMR spectrum of 5 (supplementary data) showed: A triplet signal at $\delta_{\mathrm{H}} 0.91(3 \mathrm{H})$ accounted for one terminal methyl protons; a big broad singlet signal at $\delta_{\mathrm{H}} 1.80(46 \mathrm{H})$ accounts for protons of $\mathrm{CH}_{2}$ units; a triplet signal at $\delta_{\mathrm{H}} 3.67(2 \mathrm{H})$ accounts for the protons of $\mathrm{CH}_{2}$ unit attached with electronegative hydroxyl group; a multiplet signal at $\delta_{\mathrm{H}} 1.59(2 \mathrm{H})$ assignable for the $\mathrm{CH}_{2}$ beta for the hydroxyl group. It thus could be concluded that compound $\mathbf{5}$ is 1-hexacosanol (ceryl alcohol) which is first time reported from the genus (Refaat et al., 2013).

$\boldsymbol{\beta}$-Amyrin (6, Fig. 1) was obtained as white fine needle crystals, (9 mg). Upon co-chromatography with authentic triterpenes it showed $R f$ value of 0.43 in $n$-hexane-MC $(40: 60, v / v)$ and 0.56 in $n$-hexane-EtOAc $(95: 5, v / v)$, and attained reddish brown color with spray reagent A, and violet color with Liebermann-Burchard's test (Harborne, 1998) which are the same as $\beta$-amyrin. The EI mass spectrum of 6 (supplementary data) showed a molecular ion peak at $m / z=426$ corresponds to molecular formula $\mathrm{C}_{30} \mathrm{H}_{20} \mathrm{O}$, agree with $\beta$-amyrin (Ercil et al., 2004). The fragment ion peaks $m / z=$ $218.2,203,189,175.1,135.1,95.1$ and 55.1 are also typical that of $\beta$-amyrin. It is the first report for the isolation of $\beta$-amyrin from the species.

$\boldsymbol{\beta}$-Sitosterol (7, Fig. 1) was obtained as white needle-like crystals (ether), (70 mg). The co-chromatography with authentic sterols suggests that 7 is $\beta$-sitosterol. The EIMS spectrum of 7 (supplementary data) showed a molecular ion at $\mathrm{m} / \mathrm{z} 414$, corresponding to molecular formula $\left(\mathrm{C}_{29} \mathrm{H}_{50} \mathrm{O}\right)$ of $\beta$-sitosterol. The ${ }^{1} \mathrm{H}$ NMR data (experimental section) revealed the characteristic signals of $\beta$-sitosterol as follow: A doublet signal at $\delta_{\mathrm{H}} 5.35(\mathrm{~d}, J$ $=5.2 \mathrm{~Hz}$ ) due to the olefinic proton at C-6. A multiplet $1 \mathrm{H}$ signal at $\delta_{\mathrm{H}} 3.52$ assignable for the oxymethine proton of C-3. Two singlets at $\delta_{\mathrm{H}} 1.00$ and 0.68 assignable for methyl groups of C-19 and $\mathrm{C}-18$, respectively. The ${ }^{13} \mathrm{C}$ NMR spectrum (supplementary data) showed the presence of 29 carbons (experimental section) as follow, six methyls $\left(\delta_{\mathrm{C}} 19.97,19.55,19.18,18.93,12.13\right.$ and 12.01), eleven methylenes $\left(\delta_{\mathrm{C}} 42.44,39.92,37.4,34.09,32.05\right.$, $31.8,28.4,26.22,24.45,23.21$ and 21.23$)$, nine methines $\left(\delta_{\mathrm{C}}\right.$
$121.85,71.94,56.91,56.2,50.27,45.97,36.29,32.06$ and 29.29) and three quaternary carbons $\left(\delta_{\mathrm{C}} 140.89,42.46\right.$ and 36.65). Based on these spectroscopic data and co-chromatography with the authentic sample, the compound 7 identified as $\beta$-sitosterol (Patra et al., 2010). It was previously isolated from the species (Ngounou et al., 2000).

$\boldsymbol{\beta}$-Sitosterol-3- $\boldsymbol{O}$ - $\boldsymbol{\beta}$-D-glucopyranoside (8, Fig. 1) was obtained as a white granular powder $(\mathrm{MeOH}),(29 \mathrm{mg})$. The ${ }^{1} \mathrm{H}$ NMR data showed six methyl groups at $\delta_{\mathrm{H}} 0.66(3 \mathrm{H}, \mathrm{s}), 0.83(3 \mathrm{H}, \mathrm{t}, J=7 \mathrm{~Hz})$, $0.81(3 \mathrm{H}, \mathrm{s}), 0.79(3 \mathrm{H}, \mathrm{s}), 0.96(3 \mathrm{H}, \mathrm{s})$ and $0.91(3 \mathrm{H}, \mathrm{d}, J=6.4$ $\mathrm{Hz}$ ) indicating a phytosterol skeleton (Zhao, 2014). The presence of a distinctive olefinic signal at $\delta_{\mathrm{H}} 5.33(1 \mathrm{H}, \mathrm{d}, J=4.8 \mathrm{~Hz})$ and olefinic carbons at $\delta_{\mathrm{C}} 121.15(\mathrm{C}-6)$ and 140.43 (C-5) suggests the presence of double bond. A sugar unit was evidenced from an anomeric proton at $\delta_{\mathrm{H}} 4.22(1 \mathrm{H}, \mathrm{d}, J=7.6 \mathrm{~Hz})$ with large coupling constant which pointed out the $\beta$-configuration of the glycosidic bond (Bezerra de Sá de Sousa Nogueira et al., 2013). This was confirmed by appearing of anomeric sugar carbon at $\delta_{\mathrm{C}} 100.79$ in its ${ }^{13} \mathrm{C}$ NMR.

${ }^{13} \mathrm{C}$ NMR spectrum of compound 8 indicated the presence of 35 carbons among them 6 signals $\left(\delta_{\mathrm{C}} 100.79,76.94\right.$, $76.71,73.44,70.08,61.08)$ are attributable to the glucose moiety. From the above-mentioned data, were in good agreement with published literature and co-chromatography with the authentic sample, the compound $\mathbf{8}$ was identified for $\beta$-sitosterol-3- $O-\beta$-Dglucopyranoside (Saeidnia et al., 2011). Finally, acid hydrolysis of compound $\mathbf{8}$ gave $\beta$-sitosterol (direct authentication and co-chromatography; $R f$ value of 0.43 in $n$-hexane-EtOAc (85:15, $v / v$ ) and glucose (P.C. alongside authentic sugars; $R f$ value of 0.19 in $n$-Butanol-Acetic acid- $\mathrm{H}_{2} \mathrm{O}(4: 1: 5, v / v / v)$. Compound 8 previously isolated from the species (Ngounou et al., 2000).

\section{Computer-based prediction of biological activities of isolated compounds}

Prediction of Activity Spectra for Substances (PASS ver 4.20) predicts over 4000 kinds of biological activities, including pharmacological effects, mechanisms of action, toxic and adverse effects, interaction with metabolic enzymes and transporters,.... etc. To predict biological activity profile for a compound, only structural formula is necessary thus, the prediction is possible even for compounds identified by hyphenated techniques as GC-MS or LC-MS without the need for its separation or isolation. It is reasonable that only those types of activities of compounds whose $\mathrm{Pa}>\mathrm{Pi}$ and $\mathrm{Pa}>0.700$ are very likely to have the selected activity in experiments (Ramakrishnan, 2010).

Herein, we investigated the pharmacological activities of the isolated compounds from MC fraction by PASS (ver. 4.20) computer program. The results (Table S1, Supplementary data) revealed antitumor treatment and/or prevention of some (1-3 and 6) of the isolated compounds $\mathbf{1}-\mathbf{8}$. The main predicted activities with great pa values of the $\mathbf{1}-\mathbf{3}$ and $\mathbf{6}$ compounds are antineoplastic, apoptosis agonist and proliferative diseases treatment. This provoked us to investigate MC fraction of $C$. pentandra aerial parts for its cytotoxic activity as one of the possible antineoplastic mechanisms.

Cytotoxic activity of $C$. pentandra (L.) Garten. var. pentandra: The MC fraction of $C$. pentandra was tested for its 
cytotoxic activity against HepG2 and MCF-7 cell lines using SRB method assay. The $50 \%$ inhibitory concentration $\left(\mathrm{IC}_{50}\right)$ was determined from the dose-response curve (Fig. 2). The results revealed that the $\mathrm{MC}$ fraction of $C$. pentandra exhibited clear cytotoxic activity against the two tested cell lines. The $\mathrm{IC}_{50}$ values against the cancer cell lines (HepG2 and MCF-7) were 14.895 $\mu \mathrm{g} / \mathrm{mL}$ and $18.859 \mu \mathrm{g} / \mathrm{mL}$, respectively, which is acceptable level of activity according to the national cancer institute (NCI) statement; plant extracts with cytotoxic values $\mathrm{IC}_{50} \leq 30 \mu \mathrm{g} / \mathrm{mL}$ are considered active (Alonso-Castro et al., 2011). The experimental results agreed with the results of the in silico study (Table S1, supplementary data) and worthy need further experimental investigation to explore their mechanism of action.

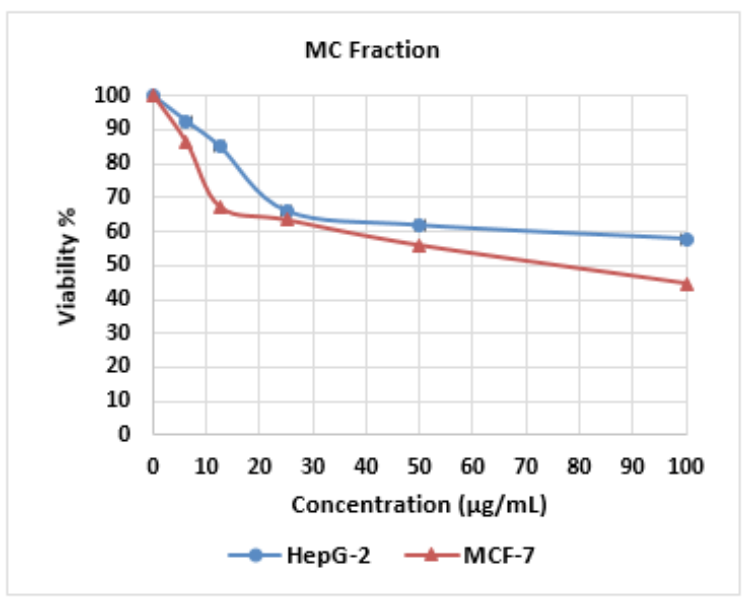

Fig. 2: Dose-cytotoxicity curves of MC fraction of C. pentandra aerial parts on HepG-2 and MCF-7 cell lines.

Previous studies concerning the antitumor activity of the Ceiba pentandra extracts, and many of our identified compounds corroborate our findings as follows: The bark extracts, namely petroleum ether, acetone, and ethanol extracts have prominent short-term cytotoxic effect on Ehrlich ascites carcinoma (EAC) cells and long-term cytotoxic effect on human breast cancer cell line (MCF-7) and melanoma cell line (B16F10) (Kumar et al., 2016). The diterpene alcohol phytol which represents about $14.99 \%$ of the identified terpene compounds in our examined extract was previously showed a promising cytotoxic activity against MCF-7 (Pejin et al., 2014) and enhanced the apoptotic mechanism (Komiya et al., 1999). Moreover, the conjugated dienoic fatty acid linoleic acid and the trienoic fatty acids $\alpha$-linolenic acid which are among the major fatty acids identified here have also reported producing cytotoxic effects on human tumor cells (Igarashi and Miyazawa, 2000).

Taraxerol and taraxerol acetate have potent anti-tumor effects through the induction of apoptosis, autophagy, inhibition of cell migration and cell cycle arrest (Hong et al., 2016; Yao et al., 2017). Moreover, squalene was reported to exhibit anti-tumor, cytotoxic properties against colon and breast cancer (Mariquit et al., 2017) and chemopreventive activities against colon carcinogenesis. $\beta$-sitosterol also was reported to inhibit tumor promotion in two stages skin carcinogenesis in a mouse model (Zakaria et al., 2017).

\section{CONCLUSIONS}

The current study shed the light on the probability of developing a new antitumor drug from $C$. pentandra or implementing its constituents in pro-drug formulations in nanoparticles. The pure isolated compounds (1-3 and 6) showed predicted antineoplastic, apoptosis agonist and proliferative diseases treatment. Other predicted biological activities of the compounds are worthy need further experimental investigation.

\section{SUPPLEMENTARY DATA}

Electronic Supplementary Material associated with this article can be found in the online version of this paper.

\section{REFERENCES}

Alagawadi K, Shah A. Anti-inflammatory activity of Ceiba pentandra L. seed extracts. J Cell Tissue Research, 2011; 11:2781-2784.

Aloke C, Nachukwu N, Idenyi J, Ugwuja E, Nwachi E, Edeogu $\mathrm{C}$, et al. Hypoglycaemic and hypolipidaemic effects of feed formulated with Ceiba pentandra leaves in alloxan induced diabetic rats. Aust J Basic \& Appl Sci, 2010; 4:4473-4477.

Alonso-Castro AJ, Villarreal ML, Salazar-Olivo LA, GomezSanchez M, Dominguez F, Garcia-Carranca A. Mexican medicinal plants used for cancer treatment: pharmacological, phytochemical and ethnobotanical studies. J Ethnopharmacol, 2011; 133:945-972.

Alvarado CR, Alvarado CA, Mendoza OO. 2002. Ceiba pentandra (L.) Gaertn. Washington DC, United States: Forest Service Publication S.1.

Anwar F, Rashid U, Shahid SA, Nadeem M. Physicochemical and antioxidant characteristics of Kapok (Ceiba pentandra Gaertn.) seed oil. J Am Oil Chem Soc, 2014; 91:1047-1054.

Bairwa NK, Sethiya NK, Mishra S. Protective effect of stem bark of Ceiba pentandra linn. against paracetamol-induced hepatotoxicity in rats. Pharmacognosy Res, 2010; 2:26-30.

Bezerra de Sá de Sousa Nogueira T, Bezerra de Sá de Sousa Nogueira R, Antas e Silva D, Tavares JF, de Oliveira Lima E, de Oliveira Pereira F, et al. First chemical constituents from Cordia exaltata Lam and antimicrobial activity of two neolignans. Molecules, 2013; 18:11086-11099.

Bezerra KdS, Antoniosi Filho NR. Characterization and quantification by gas chromatography of free steroids in unsaponifiable matter of vegetable oils. J Braz Chem Soc, 2014; 25:238-245.

Dagan S, Amirav A. Electron impact mass spectrometry of alkanes in supersonic molecular beams. J Am Soc Mass Spectr, 1995; 6:120-131.

Dass C. 2007. Fundamentals of contemporary mass spectrometry. vol. 16. Hoboken, New Jersey, USA: John Wiley \& Sons.

Djomeni PDD, Tedong L, Asongalem EA, Dimo T, Sokeng SD, Kamtchouing P. Hypoglycaemic and antidiabetic effect of root extracts of Ceiba pentandra in normal and diabetic rats. Afr J Tradit Complement Altern Med, 2006; 3:129-136.

El-Hawary SS, Mohammed R, AbouZid SF, Rateb ME, Sayed AM. Cytotoxicity of Solanum nigrum L green fruits on breast (MCF-7) and liver (HepG-2) cancer cell lines. Pharma Innovation, 2015; 3:87-89.

El-Saied HM, Amer M, Gabran A. Unsaponifiable matter and fatty acid composition of pea oil. Z Ernahrungswiss, 1981; 20:132-138.

El-Sayeda A, Hetta MH, Yassin NZ, Hassan HM, El-Awdan SA, Afifi NI. Comparative DNA profiling, phytochemical investigation, and biological evaluation of two Ficus species growing in Egypt. Pharmacognosy Res, 2013; 5:291-299.

Elumalai A, Mathangi N, Didala A, Kasarla R, Venkatesh Y. A Review on Ceiba pentandra and its medicinal features. AJP Tech, 2012; 2:83-86.

Ercil D, Sakar MK, Del Olmo E, Feliciano A. Chemical constituents of Linaria aucheri. Turk J Chem, 2004; 28:133-139.

Bolliger HR, Brenner M, Gänshirt H, Mangold HK, Seiler H, 
Stahl E, et al. 1970. Thin-Layer Chromatography, A Laboratory Handbook. 2nd ed., vol. 22. New York: Springer-Verlag Berlin-Heidelberg.

Ha LTN. 2014. Isolation of the potential compounds from ficus pumila L. Vietnam: Leaves International University HCMC.

Harborne JB. 1998. Phytochemical methods a guide to modern techniques of plant analysis. London, UK: Springer Science \& Business Media.

Hong J, Song Y, Liu Z, Zheng Z, Chen H, Wang S. Anticancer activity of taraxerol acetate in human glioblastoma cells and a mouse xenograft model via induction of autophagy and apoptotic cell death, cell cycle arrest and inhibition of cell migration. Mol Med Rep, 2016; 13:45414548 .

Houghton P, Fang R, Techatanawat I, Steventon G, Hylands PJ, Lee $\mathrm{C}$. The sulphorhodamine (SRB) assay and other approaches to testing plant extracts and derived compounds for activities related to reputed anticancer activity. Methods, 2007; 42:377-387.

Ibrahim AS, Khaled HM, Mikhail NN, Baraka H, Kamel H. Cancer incidence in Egypt: results of the national population-based cancer registry program. J Cancer Epidemiol, 2014.

Igarashi M, Miyazawa T. Newly recognized cytotoxic effect of conjugated trienoic fatty acids on cultured human tumor cells. Cancer Lett, 2000; 148:173-179.

Joshi S, Poudel TN. Isolation and characterization of the chemical constituents of Sonchus wightianus of Nepalese origin. JNCS, $2013 ; 28: 115-120$.

Koay YC, Wong KC, Osman H, Eldeen I, Asmawi MZ. Chemical constituents and biological activities of Strobilanthes crispus L. Rec Nat Prod, 2013; 7:59-64.

Komiya T, Kyohkon M, Ohwaki S, Eto J, Katsuzaki H, Imai K, et al. Phytol induces programmed cell death in human lymphoid leukemia Molt 4B cells. Int J Mol Med, 1999; 4:377-457.

Kumar R, Kumar N, Ramalingayya GV, Setty MM, Pai KSR. Evaluation of Ceiba pentandra (L.) Gaertner bark extracts for in vitro cytotoxicity on cancer cells and in vivo antitumor activity in solid and liquid tumor models. Cytotechnology, 2016; 68:1909-1923.

Lim TK. 2012. Edible Medicinal and Non-medicinal Plants, Fruits. vol. 1. New York, NY, USA: Springer Science \& Business Media.

Lunn J, Theobald $\mathrm{H}$. The health effects of dietary unsaturated fatty acids. Nutr Bull, 2006; 31:178-224.

Maeorg E, Laaniste P, Jõudu J, Maeorg U. Some important aspects of sterol analysis of vegetable oils. P Est Acad Sci, 2007; 56:59-66.

Mahato SB, Kundu AP. ${ }^{13} \mathrm{C}$ NMR spectra of pentacyclic triterpenoids a compilation and some salient features. Phytochemistry, 1994; 37:1517-1575.

Mariquit M, Oyong GG, Ng VAS, Shen C-C, Ragasa CY. Cytotoxic Compounds from Kibatalia gitingensis (Elm.) Woodson. Phcog J, 2017; 9:8-13.

Muithya JN, 2010. Phytochemical and in vitro anti-microbial screening of Echinops Hispidus Fresen. and Grewia similis K. SchumSchool of Pure and Applied Sciences, Kenyatta University.

Ngounou FN, Meli AL, Lontsi D, Sondengam BL, Atta Ur R, Choudhary MI, et al. New isoflavones from Ceiba pentandra. Phytochemistry, 2000; 54:107-110.

Patra A, Jha S, Murthy P, Sharone A. Isolation and characterization of stigmast-5-en-3 $\beta$-ol ( $\beta$-sitosterol) from the leaves of Hygrophila spinosa T. Anders. Int J Pharm Sci Res, 2010; 1:95-100.
Pejin B, Kojic V, Bogdanovic G. An insight into the cytotoxic activity of phytol at in vitro conditions. Nat Prod Res, 2014; 28:2053-2056.

Pogliani L, Ceruti M, Ricchiardi G, Viterbo D. An NMR and molecular mechanics study of squalene and squalene derivatives. Chem Phys Lipids, 1994; 70:21-34.

Priya V, Jain P, Vanathi BM, Raj PV, Kamath BV, Rao JV, et al. Methanolic root extract of Calotropis gigantea induces apoptosis in human hepatocellular carcinoma by altering Bax/Bcl-2 expression. Am J Pharmacol Sci, 2015; 3:13-17.

Sahu RK, Roy A, Matlam M, Deshmukh VK, Dwivedi J, Jha AK. Isolation of compounds from acetone extract of root wood of Moringa stenopetala and evaluation of their antibacterial activities. Res J Med Plants, 2013; 7:32-47.

Ramakrishnan A. Predication Of Biological Activity Of Algal Antitumor Drugs Using PASS. Pharmacologyonline, 2010; 3:22-34.

Refaat J, Desoky SY, Ramadan MA, Kamel MS. Bombacaceae: A phytochemical review. Pharm biol, 2013; 51:100-130.

Saeidnia S, Gohari A, Malmir M, Moradi-Afrapoli F, Ajani Y. Tryptophan and sterols from Salvia limbata. J Med Plants, 2011; 10:41-47.

Sasaki S, Aoyagi S, Hsü H. The isolation of taraxerol, taraxeryl acetate, and taraxerone from Crossostephium chinense Makino (Compositae). Chem Pharm Bull, 1965; 13:87-88.

Shiojima K, Arai Y, Masuda K, Takase Y, Ageta T, Ageta H. Mass Spectra of Pentacyclic Triterpenoids. Chem Pharm Bull, 1992; 40:1683-1690.

Sun B, Luo C, Cui W, Sun J, He Z. Chemotherapy agentunsaturated fatty acid prodrugs and prodrug-nanoplatforms for cancer chemotherapy. J Control Release, 2017; 264:145-159.

Ul-Haq I, Ullah N, Bibi G, Kanwal S, Ahmad MS, Mirza B. Antioxidant and cytotoxic activities and phytochemical analysis of Euphorbia wallichii root extract and its fractions. IJPR, 2012; 11:241.

Yao X, Lu B, Lü C, Bai Q, Yan D, Xu H. Taraxerol Induces Cell Apoptosis through A Mitochondria-Mediated Pathway in HeLa Cells. Cell J, 2017; 19:512-519.

Yin S-Y, Wei W-C, Jian F-Y, Yang N-S. Therapeutic applications of herbal medicines for cancer patients. Evid Based Complement Alternat Med, 2013; 2013:15.

Zakaria KN, Amid A, Jamal P. A Review of Anticancer, Antitumor, and Antioxidant of Clinacanthus nutans. APJMBB, 2017; 25(1):61-68.

Zhang Q, Li M, Ma H, Sun Y, Xing L. Identification and characterization of a novel $\Delta 6$-fatty acid desaturase gene from Rhizopus arrhizus. FEBS letters, 2004; 556:81-85.

Zhao J. 2014. Phytochemical and antibacterial studies on Arctium lappa, Tussilago farfara and Verbascum thapsus University of Strathclyde.

How to cite this article:

Abouelela ME, Orabi MAA, Abdelhamid RA, Abdelkader MSA, Darwish FMM. Chemical and Cytotoxic Investigation of Non-Polar Extract from Ceiba Pentandra (L.) Gaertn.: A Study Supported by Computer Based Screening. J App Pharm Sci, 2018; 8(07): 057-064. 